\title{
THE ANALYSIS OF MANAGEMENT AND UTILIZATION OF CAPITATION FUND FOR DENTISTS IN PALEMBANG AND LUBUKLINGGAU
}

\author{
Faiznur Ridho', Bambang B. Soebyakto ${ }^{1}$, Haerawati Idris ${ }^{1}$ \\ ${ }^{1}$ Department of Administration and Health Policy \\ Faculty of Public Health, Sriwijaya University, Sumatera Selatan, Indonesia \\ Correspondence Address: Faiznur Ridho \\ Email: ridho_good@yahoo.com
}

\begin{abstract}
Primary dentists in the era of the National Health Insurance were only paid IDR 2,000 for each patient. The capitation funds could not cover the service cost, and thus the payment system must be improved for the quality of service. This study analyzed the management and utilization of dental capitation funds including the bottlenecks and alternative solutions in the implementation of National Health Insurance. This study was descriptive with a qualitative approach. There were sixteen independent dentists who owned primary clinics in Palembang and Lubuklinggau with highest and lowest capitation coverage, respectively. Data were analyzed in some stages, including data reduction, presentation, conclusion and verification. Results showed that there was a disparity in capitation fund income received by dentists both as an independent practitioner and primary clinic. Not all dentists received the ideal number of patients with the ration of 1:10,000. Dentists with low capitation funds had difficulty to set their operational funds. The budget for operational cost was bigger than the service cost. Revenues compared to capitation funds were still lacking. Most capitation funds for primary dentists were insufficient and still relied on patients' fee for service. The government should set dental capitation norms and regulations in the era of National Health Insurance.
\end{abstract}

Key words: dentists, capitation, clinic, utilization, regulation.

\begin{abstract}
ABSTRAK
Dokter gigi primer di era Jaminan Kesehatan Nasional (JKN) hanya dibayar Rp 2.000 per pasien. Dana kapitasi yang didapat belum mencukupi biaya pelayanan. Sistem pembayaran harus diperbaiki karena berkaitan dengan kualitas pelayanan. Penelitian ini bertujuan untuk menganalisis pengelolaan dan pemanfaatan dana kapitasi dokter gigi primer termasuk kendala dan alternatif solusi. Penelitian ini bersifat deskriptif dengan pendekatan kualitatif. Informan penelitian dipilih secara purposive sampling yang terdiri dari 16 (enam belas) orang dokter gigi praktik mandiri dan klinik pratama di Kota Palembang dan Lubuklinggau dengan cakupan kapitasi tinggi dan rendah. Data dianalisis dengan reduksi data, penyajian data, penarikan kesimpulan dan verifikasi. Hasil penelitian menunjukkan bahwa terdapat disparitas pendapatan dana kapitasi yang diterima oleh dokter gigi baik praktik mandiri maupun sebagai klinik pratama. Tidak semua dokter gigi mendapatkan jumlah pasien yang ideal 1:10.000. Dokter gigi dengan cakupan peserta rendah kesulitan untuk memenuhi biaya operasional. Pengeluaran biaya pelayanan lebih besar dari dana kapitasi yang didapat. Sebagian besar dokter gigi masih mengandalkan pasien fee for service. Pemerintah diharapkan dapat meninjau kembali norma kapitasi dan regulasi pelayanan gigi dan mulut di era JKN.
\end{abstract}

Kata kunci: dokter gigi, kapitasi, klinik pratama, utilisasi, regulasi

\section{INTRODUCTION}

The Indonesian government has strived for equitable health services for all Indonesian. The government has implemented the National Health Insurance program through the Social Security Agency (BPJS) for health since 2014. This program aims to allow all Indonesians to obtain quality, fair, and equitable health care and protection (Ministry of Health 2014).

One of the focuses in the National Health Insurance is dental and oral health services. The World Health Organization in the 2013-2020 Regional Oral Health Strategy mentioned dental and oral diseases are the fourth most expensive diseases that need high medical expenses for treatment. According to the 2018 Basic Health 
Research, thare was an increase in the prevalence of dental and oral diseases in Indonesia from $25.9 \%$ to $57.6 \%$. From the data, only $10.2 \%$ received dental and oral health services from dental medical professional. This indicated that dental and oral health problems in Indonesia require further management.

Increase in dental and oral problems needs wise solutions. In fact, health insurance for dental, and oral health services have begun since 2014. Nevertheless, the prevalence of dental and oral diseases in Indonesia has increased. Therefore, it is necessary for evaluating causes of insufficient dental and oral health services in the era of National Health Insurance.

One of the main problems leading to poor dental and oral health care in first-level healthcare facilities was the payment method to dentists (Kazungu, JS., Barasa, EW., Obadha, M., Chuma, 2018) said that there was a relationship of financing system with the quality of health services. Relatively small capitation income wast not effective in improving doctors' performance in Indonesia (Hendrartini, 2007). Based on the Regulation of the Indonesian Ministry of Health Number 12 Year2016, fee for dentists as an independent dentist or joining primary clinic in first-level healthcare facilities was set at IDR 2000,00 per participant per month. The allocation of the capitation has not corresponded with expenses for patient health care (Budiarto, W dan Kristiana, 2015) found the average income from the capitation funds for dentists in 6 districts/cities in East Kalimantan amounted to IDR 14,203,000. 00 and the average cost to be incurred was Rp28,373,667.00. This indicated that the allocation of dental fund was not sufficient for the service cost.

South Sumatera has the third largest number of independent dentists as many as 331 dentists in Indonesia. Besides, the number of primary dental clinics, independent dentists and primary clinics using the Social Security Agency for Health was currently 173 with the largest number of clinics in Palembang and Lubuklinggau
(Ministry of Health, 2018). The total number of medical personnel and dental healthcare facilities has not made any improvement in dental and oral health care in South Sumatera province. The 2018 Basic Health Research showed there was an increase in the prevalence of dental and oral diseases in South Sumatera province from $19.5 \%$ to $52.4 \%$. Only $5.8 \%$ of patient dental and oral health services from dental medical professional. This indicated that dental and oral problems in South Sumatera requires further management..

Based on the initial survey to some dental and oral healthcare facilities in Palembang and Lubuk Linggau, some problems occurred because of inadequate capitation funds received by dentists. The first survey was conducted in Palembang among independent dental practices which have 2,300 registered participants. If each participant costs IDR 2,000 based on the predetermined capitation, dentists would receive income amounted to IDR 4,600,000. 00 (2,300 participants multiplied by IDR 2,000. 00). The expenditure in one month amounted to IDR 4,900,000. 00; the service fee costed IDR 1,500,000. 00 (30.61\%), and operational cost charged IDR 3,400,000, 00 $(69.3 \%)$. The operational cost was spent for medical consumables as much as IDR 1,400,000. 00, for electricity, telephone, and water cost as much as IDR $1,000,000.00$, for equipment maintenance as much as IDR $500,000.00$, for the purchase of stationery as much as IDR 500,000. 00.

The second survey was conducted at a primary clinic in Palembang. that the survey obtained 8770 registered participants. Based on the data, dentists should receive income amounting to IDR $17,540,000$. 00, but they only received IDR 11,100,000. 00. The assessment of the foundation commitment-based capitation has affected dentists' The result of the calculation found that the cost of expenditure to be issued was IDR 10,000,000. 00; the service fee of $\mathrm{Rp}$ $6,500,000.00$ (65 percent) divided for salary of nurses and substitute physicians as well as 
operational cost as much as IDR 3,500,000. $00(35 \%)$, for medical consumable materials as much as IDR 2,000,000. 00, for payment of electricity, water, and telephone amounting to IDR $1,000,000$. 00, and for equipment maintenance as much as IDR 500,000. 00. Based on the survey, the required authorization funds were still sufficient for the issued service cost.

The third survey was conducted inan independent dental practices in cooperation with the Social Security Agency for Health in Lubuklinggau City. There were four hundred participants registered. Dentists received income as much as IDR 800,000. 00 per month. The expenses for the operational funds were around IDR 2,000.00 per month. As a result, the funding was not sufficient for monthly expenses.

The utilization of funds for different income received became the topic to be analyzed in maintaining the quality service. Structured and in-depth research was conducted to identify the utilization of the capitation funds among dental independent practices and primary clinics. This comparison was expected to be a reference for organizing effective and efficient dental and oral health services according to the principles of quality control and cost control.

\section{METHODS}

This study used a qualitative method. Primary data were collected by conducting in-depth interview and observation through 16 independent dentists and primary clinics in Palembang and Lubuklinggau. This study selected 2 independent dentists with the highest capitation, 2 independent dentists with the lowest capitation, 2 primary clinics with the highest capitation, and 2 primary clinics with the lowest capitation in each city. The utilization of the capitation fund and whether it follows the service cost were studied further. Secondary data were obtained from monthly reports of first-level healthcare facilities, the regulation of primary healthcare center reports, and other supporting documents.

This study was conducted from February to April 2019. Data analysis was done descriptively by the means of logical thinking and experts' judgment. Data validation used triangulation between theory, method, and source. This study obtained the ethical approval from the Ethics Commission of Faculty of Public Health, Sriwijaya University No: 08/UN9.1.10/KKE/2019.

\section{RESULT}

This part explained the visit by participants with health insurance to the dentists, management of the authorization funds, and the utilization and suitability of funds received.

\section{Visits by Participants with Health Insurance to First-Level Healthcare Facilities}

Based on Tables 1 and 2, the average dental visit in Lubuklinggau city is above the normal standard $(3.14 \%)$ and the average frequency of visits is still in the safe limit $(1.83 \%)$. The highest frequency of visits in Palembang was found at the primary clinics, but at the independent dental practices in Lubuklinggau.

The results showed that there were differences in the utilization ratio of each dental care in both independent dental practices and primary clinics in Palembang and Lubuklinggau. 
Table 1. Frequency of Visits to Dental Care in Palembang in 2018

\begin{tabular}{|c|c|c|c|c|}
\hline \multirow{2}{*}{$\begin{array}{l}\text { First-Level Healthcare } \\
\text { Facilities }\end{array}$} & \multicolumn{2}{|c|}{ Number of participants } & \multirow{2}{*}{$\begin{array}{l}\text { Frequenc } \\
y \text { of visits }\end{array}$} & \multirow{2}{*}{$\begin{array}{l}\text { Utilization } \\
\text { Ratio }\end{array}$} \\
\hline & $\begin{array}{l}\text { Recipients of } \\
\text { Contribution } \\
\text { Beneficiaries }\end{array}$ & $\begin{array}{l}\text { Recipients of Non- } \\
\text { Contribution } \\
\text { Beneficiaries }\end{array}$ & & \\
\hline $\begin{array}{l}\text { Independent Dental } \\
\text { PracticeIndependent } \\
\text { Dental Practice A }\end{array}$ & 124 & 7041 & 186 & $2.59 \%$ \\
\hline $\begin{array}{l}\text { Independent Dental } \\
\text { Practice B }\end{array}$ & 2259 & 4899 & 150 & $2.09 \%$ \\
\hline $\begin{array}{l}\text { Independent Dental } \\
\text { Practice C }\end{array}$ & 311 & 2501 & 40 & $1.42 \%$ \\
\hline $\begin{array}{l}\text { Independent Dental } \\
\text { Practice D }\end{array}$ & 1052 & 1351 & 20 & $1.24 \%$ \\
\hline Primary Clinic E & 8874 & 15382 & 300 & $1.23 \%$ \\
\hline Primary Clinic $\mathrm{F}$ & 1832 & 9832 & 150 & $1.71 \%$ \\
\hline Primary Clinic $\mathrm{G}$ & 40 & 624 & 10 & $1.51 \%$ \\
\hline Primary Clinic $\mathrm{H}$ & 0 & 93 & 16 & $2.86 \%$ \\
\hline Average visit & & & 109 & $1.83 \%$ \\
\hline
\end{tabular}

Table 2. Frequency of Visits to Dental Care in Lubuklinggau in 2018

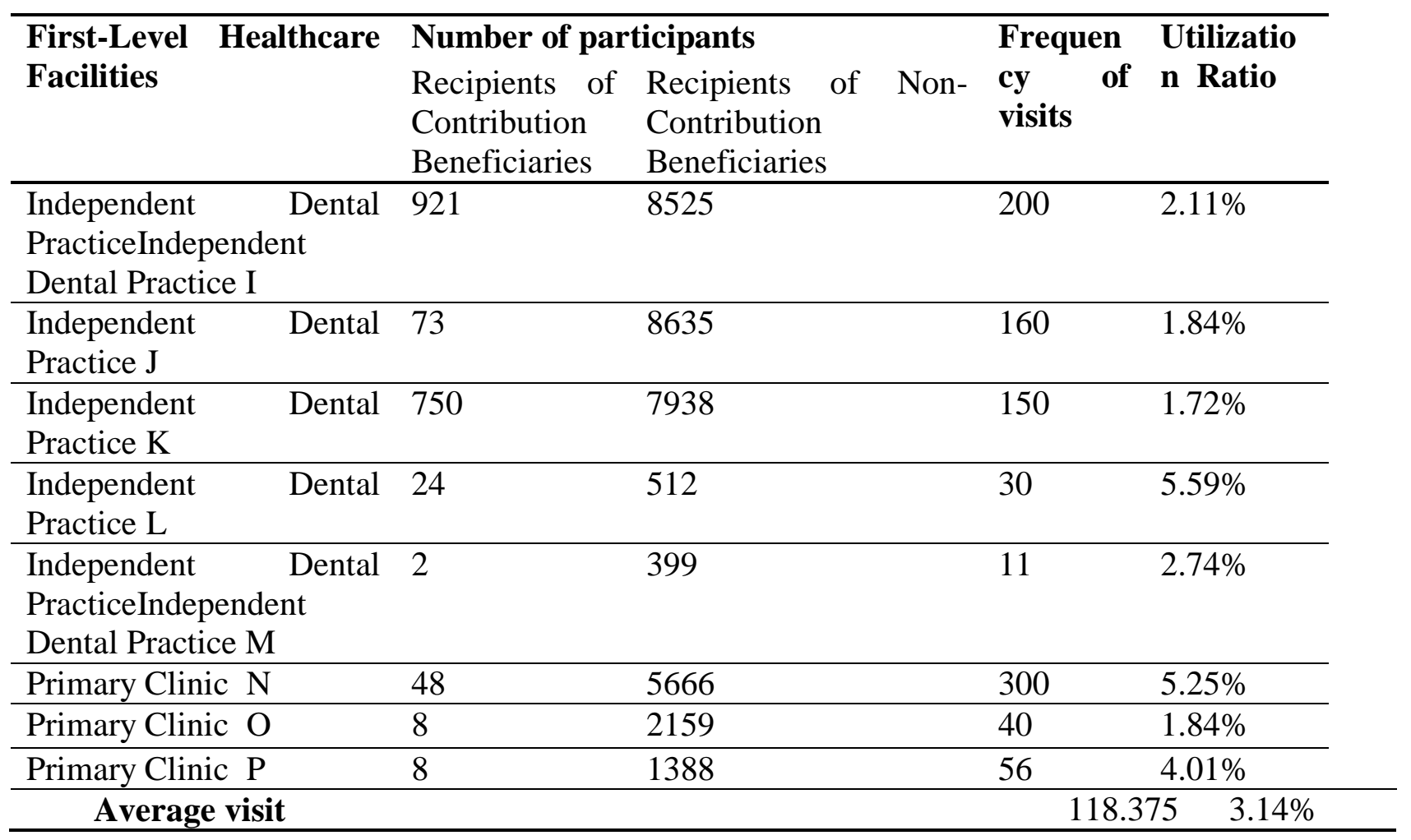

\section{Acquisition of Dental Capitation Fund}

According to Table 3, dentists received various income in Palembang according to the number of registered participants. The largest amount of capitation fund was found at the primary clinics with a total attendance of 24,256 participants and a capitation income of IDR 24,741,120. The smallest amount of capitation fund was found 
at primary clinic $\mathrm{H}$ with 93 participants and capitation income of IDR 158,100.

Table 3. Dental Care Revenues in Palembang in December 2018.

\begin{tabular}{lll}
\hline First-Level Healthcare & \multicolumn{2}{c}{ Description } \\
Facilities & \multicolumn{2}{c}{} \\
\hline Independent Dental Practice A & Number of participants (people) & 7,165 \\
\cline { 2 - 3 } & Number of capitation (IDR) & $12,180,500$ \\
\hline Independent Dental Practice B & Number of participants (people) & 7,158 \\
\cline { 2 - 3 } & Number of capitation (IDR) & $12,168,600$ \\
\hline Independent Dental Practice C & Number of participants (people) & 2,812 \\
\cline { 2 - 3 } & Number of capitation (IDR) & $4,780,400$ \\
\hline Independent Dental Practice D & Number of participants (people) & 2,403 \\
\cline { 2 - 3 } & Number of capitation (IDR) & $4,085,100$ \\
\hline Primary Clinic E & Number of participants (people) & 24,256 \\
\cline { 2 - 3 } & Number of capitation (IDR) & $24,741,120$ \\
\hline Primary Clinic F & Number of participants (people) & 11,664 \\
\cline { 2 - 3 } & Number of capitation (IDR) & $16,329,600$ \\
\hline Primary Clinic G & Number of participants (people) & 664 \\
\cline { 2 - 3 } & Number of capitation (IDR) & $1,328,000$ \\
\hline Primary Clinic H & Number of participants (people) & 93 \\
\cline { 2 - 3 } & Number of capitation (IDR) & 158,100 \\
\hline
\end{tabular}

Table 4. Capitation Income in Lubuklinggau in December 2018

\begin{tabular}{lll}
\hline First-Level Healthcare & \multicolumn{2}{c}{ Description } \\
Facilities & \multicolumn{3}{c}{} \\
\hline Independent Dental Practice I & Number of participants (people) & 9,446 \\
\cline { 2 - 3 } & Number of capitation (IDR) & $16,058,000$ \\
\hline Independent Dental Practice J & Number of participants (people) & 8,708 \\
\cline { 2 - 3 } & Number of capitation (IDR) & $14,803,000$ \\
\hline Independent Dental Practice K & Number of participants (people) & 8,698 \\
\cline { 2 - 3 } & Number of capitation (IDR) & $14,786,600$ \\
\hline Independent Dental & Number of participants (people) & 536 \\
\cline { 2 - 3 } PracticeIndependent Dental & Number of capitation (IDR) & 911,200 \\
\hline Practice L & & 401 \\
\hline Independent Dental Practice M & Number of participants (people) & 401 \\
\cline { 2 - 3 } & Number of capitation (IDR) & 681,700 \\
\hline Primary Clinic N & Number of participants (people) & 5,714 \\
\cline { 2 - 3 } & Number of capitation (IDR) & $9,713,800$ \\
\hline Primary Clinic O & Number of participants (people) & 2,167 \\
\cline { 2 - 3 } & Number of capitation (IDR) & $3,683,900$ \\
\hline Primary Clinic P & Number of participants (people) & 1,396 \\
\cline { 2 - 3 } & Number of capitation (IDR) & 2.373 .200 \\
\hline
\end{tabular}


Table 4 illustrates there are variations in the distribution and income in Lubuklinggau. The greatest amount of capitation was found at the independent dental practices with a total of 9,446 participants and capitation income of
IDR 16,058,000. While, the smallest number of capitation was found in independent dental practice $\mathrm{M}$ with 401 participants and total capitation of IDR 681,700

\section{Utilization of dentist's capitation fund}

Table 5. Utilization of Dental Capitation Fund by Independent Services in 2018

\begin{tabular}{|c|c|c|c|c|c|c|c|c|c|}
\hline \multirow[t]{3}{*}{ Type } & \multirow{3}{*}{$\begin{array}{l}\text { Type of } \\
\text { utilization }\end{array}$} & \multicolumn{4}{|c|}{ Palembang } & \multicolumn{4}{|c|}{ Lubuklinggau } \\
\hline & & \multicolumn{2}{|c|}{ High Capacity } & \multicolumn{2}{|c|}{ Low Capacity } & \multicolumn{2}{|c|}{ High Capacity } & \multicolumn{2}{|c|}{ Low Capacity } \\
\hline & & $\begin{array}{l}\text { Amoun } \\
t \text { (IDR) }\end{array}$ & $\%$ & $\begin{array}{l}\text { Amoun } \\
t \text { (IDR) }\end{array}$ & $\%$ & $\begin{array}{l}\text { Amount } \\
\text { (IDR) }\end{array}$ & $\%$ & $\begin{array}{l}\text { Amount } \\
\text { (IDR) }\end{array}$ & $\%$ \\
\hline \multirow[t]{6}{*}{ Services } & $\begin{array}{l}\text { Doctor } \\
\text { Owner }\end{array}$ & 0 & 0 & 0 & 0 & $\begin{array}{l}6,870,87 \\
7\end{array}$ & 45.16 & 0 & 0 \\
\hline & $\begin{array}{l}\text { Surrogate } \\
\text { Doctor }\end{array}$ & $\begin{array}{l}4,000,0 \\
00\end{array}$ & 29.57 & 0 & 0 & 0 & 0 & 0 & 0 \\
\hline & $\begin{array}{l}\text { Dental } \\
\text { Nurses }\end{array}$ & $\begin{array}{l}1,400,0 \\
00\end{array}$ & 10.35 & $\begin{array}{l}1,250,0 \\
00\end{array}$ & 25 & 900,000 & 5.91 & 625,000 & 11.04 \\
\hline & $\begin{array}{l}\text { Administrati } \\
\text { on }\end{array}$ & $\begin{array}{l}750,00 \\
0\end{array}$ & 5.55 & $\begin{array}{l}500,00 \\
0\end{array}$ & 10 & 600,000 & 3.94 & 300,000 & 5.3 \\
\hline & Security & $\begin{array}{l}150,00 \\
0\end{array}$ & 1.11 & 0 & 0 & 11,667 & 0.08 & 25,000 & 0.44 \\
\hline & Subtotal & $\begin{array}{l}6,300,0 \\
0\end{array}$ & 46.58 & $\begin{array}{l}1,750,0 \\
00\end{array}$ & 35 & $\begin{array}{l}8,382,53 \\
3\end{array}$ & 55.09 & 950,000 & 16.78 \\
\hline \multirow[t]{6}{*}{$\begin{array}{l}\text { Operatio } \\
\text { nal }\end{array}$} & BMHP & $\begin{array}{l}4,000,0 \\
00\end{array}$ & 29.57 & $\begin{array}{l}2,500,0 \\
00\end{array}$ & 50 & $\begin{array}{l}5,000,00 \\
0\end{array}$ & 32.86 & $\begin{array}{l}1,600,00 \\
0\end{array}$ & 28.27 \\
\hline & Electric & $\begin{array}{l}250,00 \\
0\end{array}$ & 1.85 & $\begin{array}{l}125,00 \\
0\end{array}$ & 2,5 & $\begin{array}{l}1,000,00 \\
0\end{array}$ & 6.57 & 320,000 & 5.65 \\
\hline & Water & $\begin{array}{l}225,00 \\
0\end{array}$ & 1.66 & $\begin{array}{l}125,00 \\
0\end{array}$ & 2,5 & 166,667 & 1.1 & 120,000 & 2.12 \\
\hline & Place rent & $\begin{array}{l}2,000,0 \\
00\end{array}$ & 14.79 & $\begin{array}{l}500,00 \\
0\end{array}$ & 10 & 333,333 & 2.19 & $\begin{array}{l}1,170,00 \\
0\end{array}$ & 20.67 \\
\hline & Other & $\begin{array}{l}750,00 \\
0\end{array}$ & 5.55 & & 0 & 333,333 & 2.19 & $\begin{array}{l}1,500,00 \\
0\end{array}$ & 2.65 \\
\hline & Subtotal & $\begin{array}{l}7,225,0 \\
00\end{array}$ & 53.42 & $\begin{array}{l}\text { 3,250,0 } \\
00\end{array}$ & 65 & $\begin{array}{l}\text { 6,833,33 } \\
3\end{array}$ & 44.91 & $\begin{array}{l}4,710,00 \\
0\end{array}$ & 83.22 \\
\hline
\end{tabular}

Table 5 describes the patterns of utilization of the capacity funds at the independent dental practices in Palembang and Lubuklinggau in 2018. There was a similar utilization pattern among independent dentists with high capitation fundin both Palembang and Lubuklinggau. The service cost $(53.42 \%)$ was higher than the operating cost (46.58\%). This also happened to independent dental practices with high capitation fund in Lubuklinggau, which service cost $(55.09 \%)$ was greater than the operating cost $(44.91 \%)$.

While, the independent dental practices with low-level capitation fund had the same pattern for the utilization of the capitation funds in both Palembang and
Lubuklinggau. This was, however, different from the high capitation group. Among the low capitation groups, the operational cost was greater than the service cost. Independent dental practices with low capitation fund in Palembang had the operational cost of IDR 3,250,000 (65\%) and the service cost of IDR 1,750,000 (35\%). For dental practices with low order rate in Lubuklinggau, the operational cost amounted to IDR 4,710,000 (83.22\%) and service cost of IDR 950,000 (16.78\%). In dental practices with low order rate, the dentists did not get income from the monthly capitation fund. The expense of spending is greater than the routine income of dentists. 
The operational cost was spent for consumable medical materials, electricity, water, and place rental. The operational cost was mostly spent for consumable medical materials and place rental. The service cost was allocated to salary of owners, surrogate dentists, dental nurses, administration personnel and security. Each service cost has almost similar nominal magnitude, especially for nurses, admins, and security personnel.

Table 6. Utilization of Primary Clinics in 2018

\begin{tabular}{|c|c|c|c|c|c|c|c|c|c|}
\hline \multirow[t]{3}{*}{ Type } & \multirow{3}{*}{$\begin{array}{l}\text { Type of } \\
\text { utilization }\end{array}$} & \multicolumn{4}{|c|}{ Palembang } & \multicolumn{4}{|c|}{ Lubuklinggau } \\
\hline & & \multicolumn{2}{|c|}{ High Capacity } & \multicolumn{2}{|c|}{ Low Capacity } & \multicolumn{2}{|c|}{ High Capacity } & \multicolumn{2}{|c|}{ Low Capacity } \\
\hline & & $\begin{array}{l}\text { Amoun } \\
t \text { (IDR) }\end{array}$ & $\%$ & $\begin{array}{l}\text { Amoun } \\
t \text { (IDR) }\end{array}$ & $\%$ & $\begin{array}{l}\text { Amount } \\
\text { (IDR) }\end{array}$ & $\%$ & $\begin{array}{l}\text { Amount } \\
\text { (IDR) }\end{array}$ & $\%$ \\
\hline \multirow[t]{9}{*}{ Services } & Doctor & $9,135,3$ & 44.49 & 0 & 0 & $3,135,80$ & 32.28 & & \\
\hline & Owner & 60 & & & & 0 & & & \\
\hline & Surrogate & $3,750,0$ & 18.26 & 0 & 0 & $3,428,00$ & 35.29 & $2,500,00$ & 34.97 \\
\hline & Doctor & 00 & & & & 0 & & 0 & \\
\hline & Dental & $1,650,0$ & 8.03 & $1,250,0$ & 37.8 & 650,000 & 6.69 & 650,000 & 9.09 \\
\hline & Nurses & 00 & & 00 & 8 & & & & \\
\hline & $\begin{array}{l}\text { Administrati } \\
\text { on }\end{array}$ & 0 & - & 0 & 0 & 0 & - & - & \\
\hline & Security & 0 & - & 0 & 0 & 0 & - & - & \\
\hline & Subtotal & $\begin{array}{l}\text { 14,535, } \\
360\end{array}$ & 70.78 & $\begin{array}{l}1,250,0 \\
00\end{array}$ & $\begin{array}{l}37.8 \\
8 \\
\end{array}$ & $\begin{array}{l}\text { 7,213,80 } \\
\text { 0 }\end{array}$ & 74.26 & $\begin{array}{l}\text { 3,150,00 } \\
\text { 0 }\end{array}$ & 44.06 \\
\hline \multirow{8}{*}{$\begin{array}{l}\text { Operatio } \\
\text { nal }\end{array}$} & BMHP & $4,840,0$ & 23.57 & $1,500,0$ & 45.4 & $2,000,00$ & 20.59 & $4,000,00$ & 55.94 \\
\hline & & 00 & & 00 & 6 & 0 & & 0 & \\
\hline & Electric & $\begin{array}{l}125,00 \\
0\end{array}$ & 0.61 & 50,000 & 1.51 & 500,000 & 5.15 & - & \\
\hline & Water & 35,000 & 0.17 & 0 & 0 & 0 & - & - & \\
\hline & Place rent & 0 & - & 400,00 & 12.1 & 0 & - & - & \\
\hline & & & & 0 & 2 & & & & \\
\hline & Other & $\begin{array}{l}1,000,0 \\
00\end{array}$ & 4.87 & $\begin{array}{l}100,00 \\
0\end{array}$ & 3.03 & 0 & - & - & \\
\hline & Subtotal & $\begin{array}{l}\mathbf{6 , 0 0 0 , 0} \\
00\end{array}$ & 29.22 & $\begin{array}{l}2,050,0 \\
00\end{array}$ & $\begin{array}{l}62.1 \\
2 \\
\end{array}$ & $\begin{array}{l}2,500,00 \\
0\end{array}$ & 25.74 & $\begin{array}{l}4,000,00 \\
0\end{array}$ & 55.94 \\
\hline
\end{tabular}

Table 6 describes the pattern of the utilization of the capitation funds in the primary dental clinics in Palembang and Lubuklinggau in 2018. In Palembang, those with a high level of authorization, the operational cost incurred amounted to IDR 6 million $(29.22 \%)$ and the service cost amounted to IDR 14,535,360 (70.78\%). While, primary clinics with high order rate in Lubukliggau had the operational cost of IDR 2.5 million $(25.74 \%)$ and service cost of IDR 7,213,800 (74.26\%). The high-quality primary clinics in both Palembang and Lubuklinggau showed the same pattern of utilization of the capitation fund, i.e. the service cost was greater than the operational cost.
Primary clinics with low capitation fund in Palembang had the same utilization pattern as those with low capitation fund in Lubuklinggau. Primary clinics with low capitation fund in Palembang had the operational cost of IDR 2,050,000 (62.12\%) and service cost of IDR 1,250,000 (37.88\%). Meanwhile, primary clinics with low capitation fund in Lubuklinggau earned operational cost of IDR 4 million $(55.94 \%)$ and the service cost of IDR 3,150,000 $(44.06 \%)$. The operational cost incurred was greater than the service cost. 


\section{Conformance Utilization of the Capitation Fund}

The interview conducted to independent dentists in Palembang and Lubuklinggau with income from the participants of Social Security Agency for Health showed that the income was still very volatile, and the profit was unpredictable and highly dependent on the number of patients enrolled. For dentists who did not get order, they would utilize other means to cover the shortage of the capitation funds.

"Sometimes there is a little profit due to the patient's dentures. When it is in holiday, I also will pay the doctors for patients afternoon. So far, it is enough, but sometimes it is insufficient. To cover the cost, this capitation fund is used for general patients. False dental treatment will cost different cost, such as scaling patients" (NA, 40 years old).

"When the capitation fund is used, but patients are discharged, we do not get any profit. It has less perceived benefits." (DL, 42 years old).

"If only relying on the capitation fund, it is not enough. The Social Security Agency for Health does not allocate doctor's service cost. All the disease which needs the intraoral scan might cost higher for better care, e.g. patchwork with better materials. I educate patients to receive dental care not only using the Social Security Agency for Health since most of the patients with this insurance came from middle income families. Alhamdulilah, they are willing to come again "(SZ, 28 years old $)$.

"So the capitation is not enough, honestly. I expect the cost is subsidized from the patient's service fee. Precision of work will not make our diagnosis wrong, so we do not need to repeat service. It is more efficient" (DA, 33 years old).

"If we are smart to look for minimum price for materials, it will be enough. If there are few patients, it does not cover all cost" (TR, 33 years old).

"Possible costs is estimated around 4 million as the operational expenditure for 40 patients. This is very minimal. But, if it is more than that, we need to strategically think how to cover it. If there are many patients, we often utilize our own budget. Yeah, it is kind of charity. so automatically our services are what we use for operations, so what can we do? Tired, just charity, it's in Allah we return, then we get around the precision, so the patient doesn't repeatedly "(IS, 26 years).

\section{DISCUSSION}

Tables 3 and 4, the average patient dental visit in Lubuklinggau is above the normal standard (3.14\%), and in Palembang, the average frequency of visits is still within the safe limit $(1.83 \%)$. The highest frequency of visits in Palembang was found at the primary clinics, but at independent dental practices in Lubuklinggau.

Various factors affect patient's visit to the dentists. Darmawan and (Thabrany, 2015) stated distance from healthcare facilities to patients' house can influence the frequency of patient's visits. Another factor affecting the frequency of visits was socioeconomic status. This study presented noncontribution beneficiary recipients had the highest frequency of visits Similarly, Budiasuri (2010) found a relationship between socio-economic status and frequency of visits (Yosa, A dan Wahyuni, 2015) Yosa and Wahyuni (2015) discovered when the amount of costs incurred to access health services was higher, the frequency of visits would be lower.

The distribution of national health insurance participants in Palembang and Lubuklinggau has not reached the ideal number. Ideally, one dentist could serve 10,000 participants (Dewanto, I dan Lestari, 2014). The unideal distribution affected the amount of capitation fund, both for the operational and service costs. This disparity would also affect the quality of service. (Hasan, A.G. and Adisamito, 2017) claimed large capitation fund gave free access to health care, while small amount of capitation fund limited the management, access by 
low-economic status society, decrease in performance, and accessibility of medical equipment and materials.

Tables 5 and 6 show the dentists with low capitation did not get their services. Lack of capitation fund will affect the quality of services and increase risks of number of referrals to advanced health facilities. The dentists, so far, covered the shortages by allocating funds from general patients. However, the fluctuating number of general patients could not cover these shortages. When patients had complaints of illness, doctors might give additional treatments that patients should pay more on their own. Such the action was not ethical in the health realm.

Healthcare providers should also maintain a sustainable financing system in order than patients still get decent and highquality service and the number of referrals can be suppressed. They can provide incentives to dentists with low order rate but high utilization. This system is often known as extended capitation. (Blomqvist, A dan Busby, 2012) stated that this system was a refinement of the better health financing system. With this extended capitation, the Indonesian government estimates a certain amount of funds to cover the shortage for the operational cost. Some countries, such as United Kingdom, USA, and Canada have applied this system, a scheme of the payment system for small capitation fund. Health workers can serve patients according to the prescription standards of medical services and medical indications.

The level of knowledge and dentists' wisdom are the most important supporting factors for the proper utilization of capitation fund. The research conducted by Januraga et al., (2009) found optimizing health services can be used for training and counselling, as well as other promotional, preventive, curative, and rehabilitative health care. Additionally, a good capitation fund system should be corresponding with the number of participants. The more participants, the less risks of loss. of the availability of human resources does not determine the number of participants served. The amount of capitation fund at a dental clinic should consider doctors' skills and expertise. The better the doctors' skills, the more the participants they can serve.

The capitation fund pattern puts dentists on demands of proper financial administration and management. Dentists should be able to record service administration, such as frequency of visits, type of illness, and type of action, the utilization of funds, and the pattern of financial cash flow. Renewal data on the amount of capitation fund paid are required to be collected. These should be provided along with an accountable evidence.

The financial pattern bear some risks, and thus the dentists are expected to improve health care efficiency (Thabrany, 2015). It is very different from the fee-forservice system since the dentists will not bear financial risks, causingoverutilization and supply-induced demand.

The success of the capitation fund utilization relies on the process its allocation. Dentists should be aware of allocating the existing funds to adequately cover the capitation fund from the government. The utilization of capitation fund should not only focus on curative but also promotional and preventative treatments (Dewanto, I dan Lestari, 2014).

The results showed that both independent dental practices and primary clinic have not allocated funds for the implementation of promotional and preventive programs in both Palembang and Lubuklinggau. This was contrary to the healthy paradigm that applies to the services in the era of national health insurance. This paradigm encourages individuals to have a mindset of healthy life style. The paradigm rests on improving, maintaining, and protecting health and illness recovery. It allows the community to be self-reliant in maintaining health and having higher awareness. This paradigm emphasizes on the importance of promotional and preventive programs (Endra, 2010). At the 7th meeting of the WHO Global Conference in Kenya, 
there were 3 key elements of dental hygiene mentioned. First, dental and oral health is a human right and integral part of health that affect the quality of human life. Second, dental and oral health promotion and prevention programs should be available in primary healthcare services. Third, community empowerment for dental and oral health promotion and prevention requires adequate human resources and financial policies to minimize the disparity between the rich and poor groups(Petersen, PE dan Kwan, 2010).

The promotion and prevention programs allow the dentists to perform dental care effectively and efficiently. The dentists can analyze their surrounding and social-psychographic characteristics of the participants, which reflect the habits associated with the patterns of dental and oral diseases and climate, seasonality, water, food/diet. Participant grouping can be based on low risks of illness suffered. Afterwards, the most effective dental and oral health promotion and prevention program is planned. When the community are healthy, the frequency of visits decreases. By having healthy paradigm, the dentists would get better financial protection (Dewanto, I dan Lestari, 2014).

\section{CONCLUSION}

This study concluded the rate of utilization or the frequency of dental and oral visits in Palembang was still within the ideal limit $(1.83 \%)$, but in Lubuklinggau above the ideal number $(3.14 \%)$. The largest frequency of visits in Palembang was found at the primary clinics, while Lubuklinggau had the largest frequency of visits for the independent dental practices. This frequency is influenced by geographical distance and socio-economic status. The highest ratio of patient visits was due to fewer noncontribution beneficiary recipients. In Palembang, the distribution of participants at the independent dental practices ranged from 2,000 to 7,000 participants, and the primary clinics had about 93 to 24,000 participants.
Meanwhile, in Lubuklinggau, it reached about 400 participants to 9000 participants at the independent dental practices and about 1000 to 5000 participants at the primary clinics. This number indicated an equal distribution of the national health insurance participants.

The pattern of utilization of independent dental practices and primary clinics in Palembang and Lubuklinggau was almost the same. The independent dental practices and primary clinics with low capitation fund had a greater proportion of operational cost than the service cost. The unideal distribution of participants led to giving unstable income from the capitation fund to the dentists. Promotional and preventive dental and oral programs were conducted regularly every round.

This study recommends the Indonesian Ministry of Health to evaluate the capitation payment to the dentists and the distribution of participants registered in each dental care provider. Regulations that govern the transparency of the capitation fund are required.

\section{REFERENCE}

Blomqvist, A dan Busby, C., 2012. How to Pay Family Doctors: Why "Pay per Patient" is Better Than Fee for Service. Toronto: C.D. Howe Institute.

Budiarto, W dan Kristiana, L., 2015. Pemanfaatan Dana Kapitasi Oleh Fasilitas Kesehatan Tingkat Pertama (FKTP) Dalam Penyelenggaraan JKN. Buletin Penelitian Sistem Kesehatan, 18(4), pp.437-445.

Dewanto, I dan Lestari, N., 2014. Panduan Pelaksanaan Pelayanan Kedokteran Gigi Dalam Sistem Jaminan Kesehatan Nasional. Jakarta: Pengurus Besar Persatuan Dokter Gigi Indonesia.

Endra, F., 2010. Paradigma Sehat. Saintika Medika.

Hasan, A.G. and Adisamito, W.B.B., 2017. Analisis Kebijakan Pemanfaatan 
Dana Kapitasi JKN Pada FKTP Puskesmas di Kabupaten Bogor Tahun 2016. Jurnal Kebijakan Kesehatan Indonesia, 6(3), pp.127-137. doi: https://doi.org/10.22146/jkki.v6i3.2 9658.

Hendrartini, J., 2007. Alternatif Mekanisme Pembayaran Provider dalam Asuransi Kesehatan.

Kazungu, JS., Barasa, EW., Obadha, M., Chuma, J., 2018. What characteristics of provider payment mechanisms influence health care providers behaviour? A literature review. Int J Health Plann Mgmt, 33, pp.e892-e905. doi: 10.1002/hpm. 2565.

Ministry of Health., 2018. Riset Kesehatan Dasar; RISKESDAS. Jakarta: Balitbang Kemenkes RI.

Ministry of Health, 2014 Permenkes No. 28 tahun 2014 tentang Pedoman Pelaksanaan Program Jaminan Kesehatan nasional. Jakarta.

Petersen, PE dan Kwan, S., 2010. The 7th WHO Global Conference on Health Promotion - towards integration of oral health (Nairobi, Kenya 2009). Community Dental Health, (Supplemen(27), pp.129-136.

Thabrany, H., 2015. Jaminan Kesehatan Nasional. Jakarta: Grafindo.

Yosa, A dan Wahyuni, S., 2015. FaktorFaktor Yang Berhubungan Dengan Kunjungan Pelayanan Gigi Di Puskesmas Way Laga Kota Bandar Lampung. Jurnal Analis Kesehatan, 4(2), pp.420-426. doi: http://dx.doi.org/10.26630/jak.v4i2.27 5 . 